\title{
Dynamic Responses of Multidiameter-class Fine Roots at Different Soil Depths to Thinning Measures in a Secondary Forest in China
}

\author{
Yue Pang \\ College of Forestry, Northwest A\&F University \\ Jing Tian \\ College of Forestry, Northwest A\&F University \\ Dexiang Wang ( $\square$ wangdx66@sohu.com ) \\ College of Forestry, Northwest A\&F University
}

\section{Research Article}

Keywords: Fine root dynamics, multidiameter-class fine roots, deeper soil depth, whole-tree harvesting, secondary forest

Posted Date: December 15th, 2021

DOI: https://doi.org/10.21203/rs.3.rs-1102495/v1

License: (c) (i) This work is licensed under a Creative Commons Attribution 4.0 International License. Read Full License 


\section{Abstract}

Background: Fine roots make critical contributions to carbon stocks and terrestrial productivity, and multidiameter-class fine roots exhibit functional heterogeneity. However, the dynamic characteristics of multidiameter-class fine roots at different soil depths following thinning disturbances are poorly understood. We investigated the biomass, production, mortality and turnover rate of < $0.5 \mathrm{~mm}, 0.5-1 \mathrm{~mm}$ and $1-2 \mathrm{~mm}$ fine roots at $0-20 \mathrm{~cm}, 20-40 \mathrm{~cm}$ and $40-60 \mathrm{~cm}$ soil depths under five thinning intensities $(0 \%, 15 \%$, $30 \%, 45 \%$, and $60 \%$ ) in a secondary forest in the Qinling Mountains.

Results: The biomass, production and turnover rate of $<0.5 \mathrm{~mm}$ fine roots fluctuated with increasing thinning intensity, while 0.5-1 $\mathrm{mm}$ and 1-2 $\mathrm{mm}$ fine root biomass significantly decreased. Thinning measures had no effects on fine root necromass (except for T4) or mortality. The fine root dynamic characteristics in deeper soils were more sensitive to thinning measures. Principal component analysis results show that increased $<0.5 \mathrm{~mm}$ fine root biomass and production resulted from increased shrub and herb diversity and biomass and decreased soil nutrient availability, stand volume and litter biomass, whereas 0.5-1 mm and 1-2 mm fine root biomass showed the opposite trends and change mechanisms.

Conclusions: Our results provide evidence of the positive effect of thinning on very fine root $(<0.5 \mathrm{~mm})$ biomass and production and the negative effect on thicker fine roots $(0.5-1,1-2 \mathrm{~mm})$ or all fine root $(<2 \mathrm{~mm})$ biomass. From the perspective of fine root biomass and productivity, T2 (30\%) is recommended for use in secondary forests of the Qinling Mountains. Moreover, our results suggest that thinning practices have varied effects on the dynamic characteristics of multidiameter-class fine roots.

\section{Background}

Primary forests continue to be transformed into secondary forests due to the large-scale expansion of agricultural land, highintensity commercial logging, and continuously increasing energy demands [1, 2]. In the early 21 st century, secondary forests accounted for approximately $59.5 \%$ of the global forest area [3]. Similar to primary forests, secondary forests also play important roles in habitat provision, biodiversity conservation, and carbon sink expansion [4-6]. However, the majority of secondary forests tend to have simple vegetation structures and show a loss of reproductive capacity and are vulnerable to natural disasters [7]. Accordingly, maintaining secondary forest ecosystem stability, improving productivity and stimulating ecosystem $\mathrm{C}$ sequestration are urgently needed to mitigate the greenhouse effect $[8,9]$.

Thinning operation, a key forest management practice, is widely employed to maintain secondary forest ecosystem stability and promote stand productivity by increasing stand structural heterogeneity, improving resistance and enhancing ground flora diversity $[10,11]$. Nevertheless, little is known about the impact of thinning practices on belowground productivity, although the belowground parts of vegetation make critical contributions to terrestrial productivity and carbon stock [12]. This is especially true for fine roots $(\varnothing \leq 2 \mathrm{~mm})$. Fine roots account for less than $5 \%$ of all forest biomass but for $30-50 \%$ of total net primary production [13] and for approximately $50 \%-70 \%$ of the soil C flux in forest ecosystems [14]. Unlike sampling other aboveground organic parts, sampling plant roots at the stand level is destructive, laborious and technically challenging, leading to incomplete estimations and understanding of fine root processes [15].

Abiotic and biotic factors are the main drivers of fine root dynamics (biomass, production, necromass, mortality and the turnover rate) $[16,17]$. Thinning treatments can directly modify the physical structure of trees and understory vegetation and indirectly influence belowground environmental conditions (e.g., soil fertility and microclimate), potentially impacting fine root dynamics [18, 19]. However, a few studies have reported contrasting results regarding thinning. For instance, some studies have shown that the biomass and production of fine roots generally increase following thinning due to improved soil nutrient ability and soil moisture levels $[20,21]$. In contrast, fine root biomass and production responses to thinning have been reported in other studies, including negative and negligible responses [22, 23]. Undoubtedly, exploring the underlying mechanisms of fine root dynamic responses to thinning practices will provide a theoretical basis for further understanding productivity and nutrient cycling in terrestrial ecosystems.

Fine roots were traditionally defined as roots with a diameter of $<2 \mathrm{~mm}$, and this definition has recently been debated [24]. Even in this small-diameter category ( $\varnothing \leq 2 \mathrm{~mm}$ ), fine roots of different sizes exhibit functional heterogeneity due to their different physiological activities $[25,26]$. Fine roots of $<0.5 \mathrm{~mm}$ (very fine) are mainly responsible for the acquisition and absorption of 
resources in the soil, and 0.5-2 $\mathrm{mm}$ fine roots (thicker) are responsible for resource transfer and storage [27, 28]. Very fine roots are typically more dynamic than thicker roots and are extremely sensitive to environmental change since the ratio of nonstructural to structural mass is much higher in smaller roots [20,29]. For instance, the responses of fine roots to soil nutrient and water changes are diameter dependent [30,31]. Furthermore, Ma et al. (2013) reported that very fine roots have a higher turnover rate and productivity levels than thicker roots under thinning measures. Therefore, we expect the dynamic characteristics of very fine roots to be more sensitive to thinning practices. Moreover, since thinning practices remove a large volume of aboveground organic components, leading to the death of belowground roots [32,33], we hypothesized that the necromass and mortality of fine roots would tend to increase with increasing thinning intensity.

Plants may also adjust their root systems to use resources at different soil depths [34]. When stimulated by more resource competition in surface soil, plants can adjust their roots at deep soil depths to identify more soil resources [15]. When competition for surface soil resources decreases, the exploration of deep layer soil resources is also reduced, and the plant root system will again shift to utilizing surface resources [35]. Thinning practices alter the original vegetation configuration, resulting in a change in resource competition among species that in turn leads to varied resource use strategies employed by fine roots at different soil depths [36]. Light and high-intensity thinning measures slightly or significantly reduce resource competition, leading deep soil resource exploration to decrease [21]. Under a suitable thinning treatment, understory species diversity increases and resource competition intensifies, and fine roots gradually explore deep soil resources, resulting in increased fine root biomass and production at deeper soil depths [19]. Thus, collecting samples at deeper soil depths is needed to fully quantify fine root dynamic characteristics and spatial distribution variability [37], and to clarify the resource acquisition strategies of fine roots under different thinning treatments.

In the present study, we determined the biomass, necromass, production, mortality, and turnover rate dynamics of $<0.5 \mathrm{~mm}, 0.5-1$ $\mathrm{mm}$, and $1-2 \mathrm{~mm}$ fine roots at $0-20 \mathrm{~cm}, 20-40 \mathrm{~cm}$ and $40-60 \mathrm{~cm}$ soil depths under five thinning intensities $(0 \%, 15 \%, 30 \%, 45 \%$, and $60 \%$ of the stand volume removed) in secondary forests. Our hypotheses are as follows: (a) very fine root dynamic characteristics are more sensitive to thinning practices than thicker fine roots due to their greater responsiveness to changing environments; (b) fine root necromass and mortality increase when thinning intensities increase; and (c) fine root dynamics in deep soils are more sensitive to thinning measures than those in shallow soils and exhibit fluctuations. Furthermore, to understand the driving effects of abiotic and biotic conditions on the biomass, production, necromass, mortality and turnover rate of fine roots, we explored the linkages between fine root dynamics, soil properties and stand characteristics.

\section{Results}

\section{Stand characteristics and soil properties}

Stand and soil properties changed in different ways following thinning treatments (Table 1). The volume and litter biomass significantly decreased with increasing thinning intensity $(\mathrm{p}<0.05)$, whereas the biomass and Shannon-Wiener index of shrubs and herbs showed the opposite trend $(p<0.05)$. 
Table 1

Characteristics of stand and soil (mean $\pm \mathrm{SE} ; \mathrm{n}=4$ ).

\begin{tabular}{|c|c|c|c|c|c|c|c|}
\hline Characteristic & $\begin{array}{l}\text { Depth } \\
\text { (cm) }\end{array}$ & CK & T1 & $\mathrm{T} 2$ & T3 & T4 & $p$ \\
\hline Tree & & $0 \%$ & $15 \%$ & $30 \%$ & $40 \%$ & $60 \%$ & \\
\hline $\begin{array}{l}\text { Stem density } \\
\left(\text { trees }^{-1} \mathrm{ha}^{-1}\right)\end{array}$ & & $1306 \pm 158 a$ & $1006 \pm 128 a b$ & $845 \pm 148 b$ & $614 \pm 83 b$ & $595 \pm 161 b$ & $<0.001$ \\
\hline $\mathrm{DBH}(\mathrm{cm})$ & & $16.77 \pm 1.07$ & $18.41 \pm 1.33$ & $17.74 \pm 1.13$ & $17.06 \pm 1.16$ & $17.31 \pm 0.74$ & 0.35 \\
\hline $\begin{array}{l}\text { Tree height } \\
\text { (m) }\end{array}$ & & $14.03 \pm 0.67$ & $14.72 \pm 0.97$ & $13.8 \pm 0.61$ & $13.15 \pm 0.63$ & $12.59 \pm 0.35$ & 0.16 \\
\hline $\begin{array}{l}\text { Volume }\left(\mathrm{m}^{3}\right. \\
\left.\mathrm{ha}^{-1}\right)\end{array}$ & & $250.5 \pm 21.56 a$ & $240.08 \pm 10.68 a$ & $167.33 \pm 17.14 b$ & $117.42 \pm 4.08 \mathrm{bc}$ & $105.72 \pm 16.87 \mathrm{c}$ & $<0.001$ \\
\hline \multicolumn{8}{|l|}{$\begin{array}{l}\text { Understory } \\
\text { plants }\end{array}$} \\
\hline $\begin{array}{l}\text { Shrub } \\
\text { biomass (t } \\
\text { ha }^{-1} \text { ) }\end{array}$ & & $3.41 \pm 0.06 c$ & $3.92 \pm 0.23 b c$ & $4.45 \pm 0.16 \mathrm{ab}$ & $4.94 \pm 0.21 \mathrm{ab}$ & $4.97 \pm 0.58 a$ & $<0.01$ \\
\hline $\begin{array}{l}\text { Herb } \\
\text { biomass ( } \mathrm{t} \\
\mathrm{ha}^{-1} \text { ) }\end{array}$ & & $0.62 \pm 0.04 \mathrm{~b}$ & $0.79 \pm 0.12 \mathrm{ab}$ & $0.87 \pm 0.13 a b$ & $1.02 \pm 0.12 a$ & $1.02 \pm 0.18 a$ & $<0.001$ \\
\hline $\begin{array}{l}\text { Litter } \\
\text { biomass (t } \\
\text { ha }^{-1} \text { ) }\end{array}$ & & $3.6 \pm 0.18 a$ & $2.93 \pm 0.28 a b$ & $2.78 \pm 0.31 b$ & $2.29 \pm 0.27 b c$ & $1.9 \pm 0.17 c$ & $<0.001$ \\
\hline $\begin{array}{l}\text { Shannon- } \\
\text { Wiener-herb }\end{array}$ & & $1.96 \pm 0.05 b$ & $2.13 \pm 0.08 a b$ & $2.28 \pm 0.13 a b$ & $2.22 \pm 0.13 a b$ & $2.39 \pm 0.15 a$ & $<0.05$ \\
\hline $\begin{array}{l}\text { Shannon- } \\
\text { Wiener- } \\
\text { shrub }\end{array}$ & & $1.84 \pm 0.09 b$ & $1.91 \pm 0.17 b$ & $2.25 \pm 0.03 a$ & $2.01 \pm 0.05 b$ & $2.19 \pm 0.13 a b$ & $<0.05$ \\
\hline \multicolumn{8}{|l|}{ Soil } \\
\hline \multirow{3}{*}{$\begin{array}{l}\text { Water } \\
\text { content (\%) }\end{array}$} & $0-20$ & $44.25 \pm 3.08$ & $36.01 \pm 2.6$ & $33.13 \pm 3.61$ & $44.25 \pm 3.74$ & $34.44 \pm 1.5$ & 0.051 \\
\hline & $20-40$ & $33.22 \pm 2.79$ & $29.17 \pm 1.42$ & $30.58 \pm 2.32$ & $30.46 \pm 1.65$ & $27.48 \pm 2.2$ & 0.44 \\
\hline & $40-60$ & $29.04 \pm 1.1$ & $23.3 \pm 1.13$ & $25.9 \pm 1.59$ & $26.86 \pm 1.56$ & $28.41 \pm 2.61$ & 0.18 \\
\hline \multirow{3}{*}{$\begin{array}{l}\text { Bulk density } \\
\left(\mathrm{g} \mathrm{cm}^{-3}\right)\end{array}$} & $0-20$ & $1.1 \pm 0.05$ & $1.26 \pm 0.05$ & $1.29 \pm 0.11$ & $1.1 \pm 0.05$ & $1.31 \pm 0.04$ & 0.076 \\
\hline & $20-40$ & $1.33 \pm 0.05$ & $1.41 \pm 0.05$ & $1.41 \pm 0.05$ & $1.4 \pm 0.05$ & $1.44 \pm 0.06$ & 0.63 \\
\hline & $40-60$ & $1.41 \pm 0.05$ & $1.56 \pm 0.03$ & $1.49 \pm 0.05$ & $1.48 \pm 0.04$ & $1.47 \pm 0.07$ & 0.36 \\
\hline \multirow[t]{3}{*}{$\operatorname{sOC}\left(\mathrm{g} \mathrm{kg}^{-1}\right)$} & $0-20$ & $26.64 \pm 5.08 a$ & $23.83 \pm 3.18 a$ & $9.22 \pm 0.47 b$ & $9.54 \pm 1.59 b$ & $7.37 \pm 0.55 b$ & $<0.001$ \\
\hline & $20-40$ & $14.47 \pm 1.05 a$ & $15.82 \pm 1.05 a$ & $7.65 \pm 0.47 b$ & $5.53 \pm 0.67 b$ & $5.76 \pm 0.45 b$ & $<0.001$ \\
\hline & $40-60$ & $13.34 \pm 0.78 a$ & $8.75 \pm 1.15 b$ & $5.08 \pm 0.52 c$ & $4.48 \pm 0.37 c$ & $3.77 \pm 0.2 c$ & $<0.001$ \\
\hline \multirow[t]{2}{*}{ AN $\left(\mathrm{mg} \mathrm{kg}^{-1}\right)$} & $0-20$ & $35.56 \pm 2.65 a$ & $29.37 \pm 3.93 a$ & $10.07 \pm 0.98 b$ & $9.14 \pm 0.42 b$ & $7.96 \pm 0.4 b$ & $<0.001$ \\
\hline & $20-40$ & $16.64 \pm 1.58 a$ & $16.01 \pm 1.38 a$ & $7.97 \pm 0.14 b$ & $6.95 \pm 0.6 b$ & $6.37 \pm 0.18 b$ & $<0.001$ \\
\hline
\end{tabular}

Note: DBH, SOC, AN, AP and AK: diameter at breast height, soil organic carbon, available nitrogen, available phosphorus, available potassium. CK, T1, T2, T3, T4 representing $0 \%, 15 \%, 30 \%, 45 \%$ and $60 \%$ thinning intensity, respectively. Different letters $(a, b, c, d)$ indicate significant differences between different thinning intensity $(p<0.05)$. 


\begin{tabular}{|c|c|c|c|c|c|c|c|}
\hline Characteristic & $\begin{array}{l}\text { Depth } \\
\text { (cm) }\end{array}$ & CK & $\mathrm{T} 1$ & $\mathrm{~T} 2$ & T3 & $\mathrm{T} 4$ & $p$ \\
\hline & $40-60$ & $9.37 \pm 1.33 a$ & $7.59 \pm 0.94 a b$ & $7.19 \pm 0.32 \mathrm{ab}$ & $5.52 \pm 0.36 \mathrm{bc}$ & $4.95 \pm 0.12 c$ & $<0.01$ \\
\hline \multirow[t]{3}{*}{$\mathrm{AP}\left(\mathrm{mg} \mathrm{kg}^{-1}\right)$} & $0-20$ & $4.38 \pm 0.74 a$ & $3.58 \pm 0.39 a b$ & $3.15 \pm 0.41 \mathrm{ab}$ & $1.84 \pm 0.28 b$ & $2.16 \pm 0.3 b$ & $<0.01$ \\
\hline & $20-40$ & $2.46 \pm 0.29 a b$ & $3.15 \pm 0.54 a$ & $1.95 \pm 0.33 a b$ & $1.36 \pm 0.16 b$ & $1.18 \pm 0.18 b$ & $<0.01$ \\
\hline & $40-60$ & $1.86 \pm 0.24 a$ & $1.78 \pm 0.08 \mathrm{a}$ & $1.12 \pm 0.06 b$ & $0.73 \pm 0.04 c$ & $0.71 \pm 0.1 c$ & $<0.001$ \\
\hline \multirow[t]{3}{*}{$\mathrm{AK}\left(\mathrm{mg} \mathrm{kg}^{-1}\right)$} & $0-20$ & $156.19 \pm 11.78 a b$ & $185.2 \pm 7.26 a$ & $134.78 \pm 12.64 b$ & $146.29 \pm 5.87 a b$ & $110.81 \pm 12.08 b$ & $<0.01$ \\
\hline & $20-40$ & $110.49 \pm 6.98 a$ & $97.33 \pm 9.32 a b$ & $101.85 \pm 6.63 \mathrm{ab}$ & $80.37 \pm 8.67 a b$ & $77.15 \pm 7.71 b$ & $<0.05$ \\
\hline & $40-60$ & $91.69 \pm 12.45 a$ & $96.3 \pm 11.96 a$ & $45.27 \pm 5.39 b$ & $42.49 \pm 6.26 b$ & $43.88 \pm 4.38 b$ & $<0.001$ \\
\hline \multirow[t]{3}{*}{$\mathrm{pH}$} & $0-20$ & $6.29 \pm 0.14$ & $6.14 \pm 0.11$ & $6.38 \pm 0.08$ & $6.42 \pm 0.14$ & $6.6 \pm 0.07$ & 0.11 \\
\hline & $20-40$ & $5.99 \pm 0.18$ & $6.02 \pm 0.09$ & $6.07 \pm 0.17$ & $6.28 \pm 0.08$ & $6.37 \pm 0.04$ & 0.18 \\
\hline & $40-60$ & $5.75 \pm 0.09 b$ & $6.11 \pm 0.05 a$ & $6.1 \pm 0.09 a$ & $6.21 \pm 0.07 a$ & $6.37 \pm 0.08 a$ & $<0.05$ \\
\hline
\end{tabular}

Table 2

Simplified decision matrix for calculating the production and mortality of fine root.

\begin{tabular}{lll} 
If & Fine root production & Fine root mortality \\
\hline$\Delta L+\Delta D \geqq 0$ and $\Delta D \geqq 0$ & $\Delta L+\Delta D$ & $\Delta D$ \\
$\Delta L \geqq 0$ and $\Delta D \leqq 0$ & $\Delta L$ & $|\Delta L|$ \\
$\Delta L \leqq 0$ and $\Delta D \leqq 0$ & 0 & 0 \\
$\begin{array}{l}\text { Note: } L: \text { live fine root mass; } \mathrm{D} \text { : dead fine root mass; } \Delta \text { represents the changes in living fine root biomass or necromass. The } \\
\text { vertical bars indicate the absolute values. The inequalities in the first column on the left indicate the conditions for the on the } \\
\text { change value of fine root biomass and necromass. }\end{array}$
\end{tabular}

SOC, AN, AP and AK, water content and pH values decreased with increasing soil depth, while the soil bulk density increased. T2, T3 and T4 had significantly lower SOC, AN, AP and AK values than CK values, decreasing by 47.1-72.3\%, 23.2-77.6\%, 18.7-61.8 and 6.3$53.6 \%(p<0.05)$, respectively. Thinning had no significant effects on soil water content, bulk density or $\mathrm{pH}(\mathrm{p}>0.05)$ (except for $\mathrm{pH}$ at $40-60 \mathrm{~cm})($ Table 1$)$.

\section{Fine root biomass, necromass, and total mass of different diameter classes}

The whole fine root system $(\varnothing \leq 2 \mathrm{~mm})$ biomass $(F=2.11, p>0.05)$, necromass and total mass $(F=2.33, p>0.05)$ values of total soil depth $(0-60 \mathrm{~cm})$ on average did not differ among the treatments, except for the significant increase in necromass occurring in $\mathrm{T} 4(\mathrm{~F}=25.31, \mathrm{p}<0.01)$ (Figure $2 \mathrm{~d}, \mathrm{~h}, \mathrm{I}$ and Table 3$)$. The very fine root $(<0.5 \mathrm{~mm})$ biomass and total mass fluctuated with increasing thinning intensity. The very fine root biomass $(F=10.91, p<0.01)$ and total mass $(F=10.62, p<0.01)$ in T1 and T3 were significantly lower than those in CK, while those in T2 and T4 exceeded those in CK (although not significant) (Figure 2d, I and Table 3). The 0.5-1 mm ( $F=4.42, p<0.05)$ and $1-2 \mathrm{~mm}(F=9.01, \mathrm{p}<0.01)$ fine root biomass and $1-2 \mathrm{~mm}(F=4.15, p<0.05)$ total 
mass decreased following thinning intensity, reaching significance at T3 and T4 (Figure 2d, I and Table 3). The 0.5-1 mm and 1-2 $\mathrm{mm}$ fine root necromass mirrored the overall fine root system necromass dynamics, whereas very fine root necromass was rarely observed (Figure 2h).

Table 3

The effects of thinning intensity $(\mathrm{T})$ on mean annual biomass, necromass, and total biomass of fine roots over the entire soil profile and in specific depth (D).

\begin{tabular}{|c|c|c|c|c|c|c|}
\hline Characteristic & df & Source & $<0.5 \mathrm{~mm}$ & $0.5-1 \mathrm{~mm}$ & $1-2 \mathrm{~mm}$ & $<2 \mathrm{~mm}$ \\
\hline \multicolumn{7}{|l|}{ Entire soil profile } \\
\hline Biomass $\left(\mathrm{g} \mathrm{m}^{-2}\right)$ & 4 & $\mathrm{~T}$ & $10.91^{\star \star}$ & $4.42^{\star}$ & $9.01^{\star *}$ & 2.11 \\
\hline Necromass $\left(\mathrm{g} \mathrm{m}^{-2}\right)$ & 4 & $\mathrm{~T}$ & 2.34 & $58 * \star$ & $11.11^{\star \star}$ & $25.31^{\star \star}$ \\
\hline Total mass $\left(\mathrm{g} \mathrm{m}^{-2}\right)$ & 4 & $\mathrm{~T}$ & $10.62^{\star \star}$ & 2.33 & $4.15^{\star}$ & 2.33 \\
\hline \multicolumn{7}{|c|}{ Depth-specific response } \\
\hline \multirow[t]{3}{*}{ Biomass $\left(\mathrm{g} \mathrm{m}^{-2}\right)$} & 4 & $\mathrm{~T}$ & $19.05^{\star \star}$ & $11.75^{\star \star}$ & $16.57^{\star \star}$ & $12.15^{\star \star}$ \\
\hline & 2 & $\mathrm{D}$ & $1620 * \star$ & $894^{\star \star}$ & $1621^{\star \star}$ & $3488 * \star$ \\
\hline & 8 & $T \times D$ & $9.12^{\star \star}$ & $6.44^{\star \star}$ & $6.91^{\star \star}$ & $12.58^{* \star}$ \\
\hline \multirow[t]{3}{*}{ Necromass $\left(\mathrm{g} \mathrm{m}^{-2}\right)$} & 4 & $\mathrm{~T}$ & $6.58^{\star \star}$ & $4.35^{\star \star}$ & $10.82^{\star \star}$ & $13.57^{\star \star}$ \\
\hline & 2 & $D$ & $17.74^{\star \star}$ & $57 \star \star$ & $431^{\star \star}$ & $580 * \star$ \\
\hline & 8 & $T \times D$ & 1.46 & $2.17^{\star}$ & $6.64 * \star$ & $8.03^{\star \star}$ \\
\hline \multirow[t]{3}{*}{ Total mass $\left(\mathrm{g} \mathrm{m}^{-2}\right)$} & 4 & $\mathrm{~T}$ & $17 * *$ & $6.15^{\star \star}$ & $9.93^{\star \star}$ & $8.85^{\star \star}$ \\
\hline & 2 & D & 1558 ** & $1074 \star \star$ & $2201^{\star \star}$ & $4109 * \star$ \\
\hline & 8 & $T \times D$ & $8.49 \star \star$ & $7.9 * *$ & $9.30 * \star$ & $13.56^{* *}$ \\
\hline
\end{tabular}

Fine root biomass, necromass, and total mass decreased with soil depth, and the values in the topsoil $(0-20 \mathrm{~cm})$ accounted for more than $70 \%$ of the total values for all soil depths (Figure 2). Biomass and the total mass of very fine roots were mainly distributed in topsoil and accounted for approximately $50 \%$ of the values in the topsoil and $40 \%$ of the total values. The biomass and total mass of 0.5-1 mm and 1-2 mm roots dominated the deep soil depths, while the necromass of 0.5-1 mm and 1-2 mm roots was dominant at all soil depths (Figure 2). The very fine root biomass and total mass were more sensitive to thinning measures than those of other size classes across all soil depths (Table 3 and Figure 2). The fine root biomass, necromass, and total mass at middle and deep soil depths exhibited greater percentage changes than those in topsoil following thinning, and these dynamics in the deep soil increased again in T3 and T2 (Figure 2 and Table 4). 
Table 4

Mean percentage changes of fine root characteristics within different diameter classes

for all thinning treatments in different soil depths (mean $\pm S E ; n=4$ ).

\begin{tabular}{|c|c|c|c|c|}
\hline Characteristic & Diameter(mm) & $0-20 \mathrm{~cm}$ & $20-40 \mathrm{~cm}$ & $40-60 \mathrm{~cm}$ \\
\hline \multirow[t]{3}{*}{ Biomass (\%) } & $<0.05$ & $21.44 \pm 6.75$ & $32.92 \pm 8.26$ & $42.23 \pm 10.18$ \\
\hline & $0.5-1$ & $9.05 \pm 2.54$ & $38.02 \pm 8.54$ & $14.39 \pm 7.43$ \\
\hline & $1-2$ & $15.14 \pm 4.88$ & $17.68 \pm 5.01$ & $42.51 \pm 4.39$ \\
\hline \multirow[t]{3}{*}{ Necromass (\%) } & $<0.05$ & $36.17 \pm 13.27$ & NA & $76.42 \pm 25.86$ \\
\hline & $0.5-1$ & $16.51 \pm 5.91$ & $27.23 \pm 19.99$ & $33.95 \pm 11.6$ \\
\hline & $1-2$ & $20 \pm 10.36$ & $46.4 \pm 12.96$ & $30.63 \pm 7.89$ \\
\hline \multirow[t]{3}{*}{ Total mass (\%) } & $<0.05$ & $21.35 \pm 6.66$ & $32.38 \pm 7.95$ & $41.23 \pm 9.84$ \\
\hline & $0.5-1$ & $7.45 \pm 2.72$ & $33.96 \pm 7.4$ & $15.06 \pm 6.39$ \\
\hline & $1-2$ & $10.01 \pm 1.74$ & $17.34 \pm 3.07$ & $41.08 \pm 3.01$ \\
\hline \multirow[t]{3}{*}{ Production (\%) } & $<0.05$ & $40.04 \pm 14.25$ & $19.74 \pm 4.09$ & $62.29 \pm 9.94$ \\
\hline & $0.5-1$ & $19.22 \pm 5.27$ & $16.52 \pm 4.95$ & $23.83 \pm 10.96$ \\
\hline & $1-2$ & $20.62 \pm 6.28$ & $25.19 \pm 10.41$ & $57.37 \pm 8.42$ \\
\hline \multirow[t]{3}{*}{ Mortality (\%) } & $<0.05$ & $39.83 \pm 14.89$ & $46.03 \pm 17.65$ & $57.21 \pm 6.48$ \\
\hline & $0.5-1$ & $36.03 \pm 9.42$ & $42.48 \pm 7.92$ & $37.38 \pm 5.89$ \\
\hline & $1-2$ & $36.03 \pm 6.28$ & $55.04 \pm 11.02$ & $62.4 \pm 1$ \\
\hline \multirow[t]{3}{*}{ Turnover rate (\%) } & $<0.05$ & $48.21 \pm 8.83$ & $29.93 \pm 11.18$ & $52.15 \pm 8.83$ \\
\hline & $0.5-1$ & $32.98 \pm 6.62$ & $59.15 \pm 27.89$ & $33.92 \pm 9.27$ \\
\hline & $1-2$ & $19.82 \pm 5.21$ & $21.07 \pm 9.96$ & $33.33 \pm 9.13$ \\
\hline
\end{tabular}

The fine root biomass, necromass, and total mass exhibited strong seasonal variations within the sampling year (Figure 3, Figure S1-2 and Table S1). The fine root biomass and total mass peaked in spring as determined by very fine root biomass levels (Figure 3 and Figure S2). The fine root necromass peaked in the autumn, as did the 0.5-1 mm and 1-2 mm fine root necromass (Figure S1).

\section{Fine root production, mortality and turnover rate in different diameter classes}

The whole fine root system $(\varnothing \leq 2 \mathrm{~mm})$ production and mortality of the entire soil profile $(0-60 \mathrm{~cm})$ and the averaged turnover rate did not differ among different thinning intensities (all $p>0.05$ ) (Figures $4 d, h, I$ and Table 5). Very fine root production also

fluctuated following thinning and significantly exceeded that of the CK in T2 and T4 ( $F=5.7, p<0.01$ ) (Figure 4d and Table 5). The very fine root turnover rate in T3 was significantly lower than that at the other thinning intensities $(F=2.71, p<0.05)$ (Figure $4 \mathrm{l}$ and Table 5). Thinning practices did not affect the production and turnover rate of 0.5-1 mm and 1-2 $\mathrm{mm}$ fine roots (all $\mathrm{p}>0.05)$ (Figure 4d, I and Table 5). The 0.5-1 mm fine root mortality value in T1 was higher than that under the other treatments $(F=5.27, p<0.01)$. The 0.5-1 mm and 1-2 mm fine root mortality levels mirrored the total mortality levels (Figure $4 \mathrm{~h}$ and Table 5). 
Table 5

The effects of thinning intensity $(T)$ on annual production, mortality, and turnover rate of fine roots over the entire soil profile and in specific depth (D).

\begin{tabular}{|c|c|c|c|c|c|c|}
\hline Characteristic & df & Source & $<0.5 \mathrm{~mm}$ & $0.5-1 \mathrm{~mm}$ & $1-2 \mathrm{~mm}$ & $<2 \mathrm{~mm}$ \\
\hline \multicolumn{7}{|l|}{ Entire soil profile } \\
\hline Production $\left(\mathrm{g} \mathrm{m}^{-2}\right)$ & 4 & $\mathrm{~T}$ & $5.7 \star \star$ & 0.39 & 1.5 & 0.75 \\
\hline Mortality $\left(\mathrm{g} \mathrm{m}^{-2}\right)$ & 4 & $\mathrm{~T}$ & 1.32 & $5.27 \star \star$ & 2.2 & 2.23 \\
\hline Turnover $\left(\right.$ year $^{-1}$ ) & 4 & $\mathrm{~T}$ & $3.27 *$ & 0.77 & 0.63 & 0.63 \\
\hline \multicolumn{7}{|c|}{ Depth-specific response } \\
\hline \multirow[t]{3}{*}{ Production $\left(\mathrm{g} \mathrm{m}^{-2}\right)$} & 4 & $\mathrm{~T}$ & 2.11 & 0.52 & 2.12 & 2.52 \\
\hline & 2 & $\mathrm{D}$ & $126.65^{\star \star}$ & 0.53 & $40.43^{\star *}$ & 153.64 ** \\
\hline & 8 & $T \times D$ & $5.49 * \star$ & 1.05 & 1.94 & $2.96^{\star}$ \\
\hline \multirow[t]{3}{*}{ Mortality $\left(\mathrm{g} \mathrm{m}^{-2}\right.$ ) } & 4 & $\mathrm{~T}$ & 1.25 & 1.52 & 1.62 & 1.23 \\
\hline & 2 & $\mathrm{D}$ & 0.7 & $47.3^{\star \star}$ & $125.66^{\star *}$ & $123.36 * *$ \\
\hline & 8 & $T \times D$ & 0.82 & $2.23^{\star}$ & $6.11^{\star \star}$ & $2.36^{\star}$ \\
\hline \multirow[t]{3}{*}{ Turnover $\left(\right.$ year $^{-1}$ ) } & 4 & $\mathrm{~T}$ & 1.5 & 1 & 0.66 & 1.93 \\
\hline & 2 & $\mathrm{D}$ & 2.97 & $4.94^{*}$ & 1.54 & $8.34^{\star *}$ \\
\hline & 8 & $T \times D$ & $2.63^{\star}$ & 1.26 & 2 & 1.77 \\
\hline
\end{tabular}

The production and mortality of fine roots decreased with soil depth, and the values in topsoil accounted for approximately $69 \%$ of total production and $71 \%$ of the total mortality (Figure 4). The production of very fine roots also occupied the topsoil and accounted for approximately $51 \%$ in the topsoil and $35 \%$ of the total value. Fine root mortality of $1-2 \mathrm{~mm}$ was greater at all soil depths (Figure $4 \mathrm{e}, \mathrm{f}, \mathrm{g}$ ). The fine root turnover rate generally increased with deepening soil depths (Figure $4 \mathrm{i}, \mathrm{j}, \mathrm{k}$ ). The very fine root production and turnover rate were more sensitive to thinning measures than those of other size classes among the soil depths (Table 5 and Figure 4). The percentage changes in fine root production, mortality and turnover rates in deep soil layers were also generally higher than those in topsoil following thinning, and these dynamics in the deep soil were enhanced again in T2 (Figures 4 and Table 4).

\section{The linkages between fine root dynamics and stand and soil attributes}

The PCA of the entire soil profile according to standardized data shows that the first two trait axes accounted for $32.3 \%$ and $14.3 \%$ of the total variation, respectively (Figure 5). We found that the 0.5-1 $\mathrm{mm}$ and 1-2 $\mathrm{mm}$ fine root biomasses were highly positively related to soil properties (SOC, AN, AP and AK) and stand characteristics (volume and litter biomass) but negatively correlated with the diversity index and biomass of shrubs and herbs. Conversely, the biomass, production, and turnover rate of very fine roots and the necromass of 0.5-1 $\mathrm{mm}$ and 1-2 $\mathrm{mm}$ fine roots were negatively correlated with soil nutrient availability, stand volume and litter biomass, whereas they exhibited strong positive correlations with the diversity index and the biomass of shrubs and herbs. The PCA of individual soil depths shows that the association between the understory vegetation characteristics and the very fine root portion was stronger in the topsoil, whereas this correlation disappeared with the thicker fine root portion appearing at deeper soil depths (Figure S3).

\section{Discussion}

\section{Effects of thinning on fine root biomass, production and turnover rate}


Consistent with our hypothesis, we found that very fine root biomass, production and turnover rates were more sensitive to thinning practices than thicker fine roots. The results align with a recent observation that forest cutting has more significant effects on fine roots than on thicker roots [23]. These results may be attributed to the fact that fine roots of different diameter classes exhibit heterogeneous physiological functions and structural compositions, leading to discrepant responses following thinning practices [26]. Moreover, a similar study found that very fine roots with a higher ratio of nonstructural to structural mass are more sensitive to changes in abiotic or biotic factors caused by thinning practices [29].

The very fine root biomass, production and turnover rate levels fluctuated (positive or negative effect) with increasing thinning intensity, which is inconsistent with positive or negative results obtained following thinning in previous studies [12, 33]. Regarding positive effects, our PCA results suggest that the increase in the biomass and productivity of very fine roots resulted from increases in herb and shrub layer species diversity and biomass (especially in topsoil) (Figures 5 and S3 a), which compensated for decreased fine root biomass and production resulting from cutting canopy trees, consistent with early studies [19, 32]. In addition, previous research has demonstrated that low-nutrient conditions can stimulate the growth of fine root biomass and productivity [54]. In the present study, our whole-tree harvesting measures (reduced stand volume and liter biomass) increased the export of nutrients and reduced soil nutrient availability (Table 1), consistent with an early study [55]. Furthermore, the PCA results show that very fine root biomass and production were negatively correlated with soil nutrient availability, stand volume and liter biomass, supporting this view. Regarding negative effects, a possible explanation is that thinning practices reduce resource competition pressure, and low fine root biomass, production and turnover rate values may satisfy vegetation resource absorption and utilization requirements [56].

In contrast, we found that thinning treatments significantly reduced the biomass of $0.5-1 \mathrm{~mm}$ and $1-2 \mathrm{~mm}$ fine roots, supporting the negative effect of thinning found in previous studies [57]. On the one hand, our PCA results indicate that thinning practices reduced stand volume and litter biomass, which may decrease photosynthate partitioning to the root system and ultimately lead to the reduced biomass and productivity of 0.5-1 $\mathrm{mm}$ and $1-2 \mathrm{~mm}$ fine roots [23]. Early studies reported that the nutrient acquisition strategy for thicker fine roots may be achieved by increasing their lifespan and extending the period of nutrient absorption, which is strongly dependent on nutrient availability $[25,58,59]$. Our PCA results show that $0.5-1 \mathrm{~mm}$ and $1-2 \mathrm{~mm}$ fine root biomass was positively correlated with soil nutrient availability and negatively correlated with herb and shrub species diversity and biomass. Therefore, decreased stand volume, litter biomass and nutrient availability following thinning measures together reduced 0.5-1 mm and 1-2 mm fine root biomass. Overall, our findings provide a reasonable explanation for the inconsistent impacts of thinning practices on fine root biomass and production observed in previous studies [12,33]. The positive effects of thinning on fine roots are due to significantly stimulated growth in very fine root biomass and productivity. Regarding negative effects, on the one hand, thinning reduces all diameter classes of fine root biomass. On the other hand, thinning significantly reduces $0.5-1 \mathrm{~mm}$ and $1-2 \mathrm{~mm}$ fine root biomass, which is not compensated for by the stimulation of very fine roots (Figure 2) $[23,60]$.

A previous study found the recovery and growth of remaining stand productivity after thinning to be determined by fine root productivity [32]. Furthermore, very fine roots $(<0.5 \mathrm{~mm})$ are mainly responsible for the acquisition and uptake of soil resources [27, 61]. In this study, very fine root biomass and productivity exceeded CK in the T2 and T4 treatments, and productivity reached a significant level before biomass. This result corresponds with the results of Yuan and Chen (2012) [62], who found fine root production to peak much sooner than fine root biomass, indicating that stands under the T2 and T4 treatments would present higher productivity and increased biomass in subsequent development. However, compared to T2, T4 removed excessive aboveground organic components, which were difficult to recover in a short period time [63]. In terms of fine root biomass and productivity, our results reveal that a $30 \%$ approach (T2: moderately reduced aboveground biomass) may be a more suitable thinning strategy for promoting productivity and increasing stand heterogeneity in forest ecosystems. Previous studies have also reported that root gaps in forests recover faster and are more ephemeral than canopy gaps after thinning [64, 65], demonstrating that fine root characteristics serve as very valuable data for the selection of suitable thinning intensity. Moreover, our findings align with traditional studies showing that a moderate thinning intensity could better improve stand productivity and increase the diversity of understory plants compared to other thinning intensities $[66,67]$.

\section{Necromass and mortality changes following thinning}

In this study, thinning intensity had no influence on the fine root necromass of the entire soil profile (except for T4). Our observed dynamics of fine root necromass are inconsistent with the results of Wang et al. (2019) and Ma et al. (2013) [19], who found 
thinning practices to decrease or increase necromass. On the one hand, previous studies have demonstrated that the biomass and necromass of very fine roots account for a greater proportion of the fine root system than other root size classes [29], and our very fine root biomass results support this conclusion, which may theoretically determine the necromass. However, very fine roots also possess higher nonstructural carbohydrate concentrations and decompose more easily; thus, these roots are rarely observed [47, $68,69]$. On the other hand, thinning measures may improve soil conditions (e.g., soil temperature, Figure S4) and may also further increase the fine root decomposition rate [33]. Thus, fine root necromass levels did not differ between treatments, potentially due to a large amount of fine root necromass decomposing and disappearing [70,71]. We note that, however, T4 exhibited significantly increased necromass levels. This finding may be attributable to the fact that high-intensity thinning and species replacement produced a large amount of fine root necromass [35, 37], especially for 0.5-1 $\mathrm{mm}$ and 1-2 $\mathrm{mm}$ fine roots, which had not completely decomposed, resulting in a significant increase in necromass in T4.

A previous study showed that the thinning of stands leads to relief from root competition for soil resources and increased average root longevity, resulting in a reduction in root mortality [72]. However, we found that thinning practices did not influence the fine root mortality of the entire soil profile. It may be that whole-tree harvesting measures caused a high degree of resource loss (especially nutrient loss) [55], which counteracted the resource competitive pressure relieved by thinning and led to mortality in thinning stands comparable to that of undisturbed forest stands. The significantly higher mortality of 0.5-1 mm fine roots observed in T1 supports this explanation (Figure 4h). Given the high variability in root responses observed, further experiments are needed to measure fine root necromass and mortality in different diameter classes and to determine the factors that drive the disappearance of very fine root necromass following thinning [63].

\section{Response of deeper soil fine root dynamic characteristics to thinning}

As hypothesized, we found thinning effects on fine root dynamic characteristics to be stronger at deep soil depths, and fine root dynamics exhibited fluctuating patterns. These findings are consistent with the results of a recent study showing dramatically altered fine root biomass and necromass levels at deeper soil depths following thinning [23]. This response may reflect the resource acquisition strategy of the root system following thinning. In the topsoil layer, the fine root systems of shallow root understory plants and the remaining trees quickly colonize and recover in the area liberated by the disturbance; thus, these roots are less affected by thinning practices $[22,63]$. It is well known that trees and understories jointly determine the dynamics of roots in the surface soil layer due to belowground niche partitioning, while trees determine such dynamics at deep soil depths (Figure S3) [73, 74]. In our study, all four thinning intensities reduced fine root biomass and productivity at deep soil depths (Figures 2 and 4 ), which may be because these practices reduced the fine root densities of trees and consequently alleviated resource competition pressure at this depth [72]. Compared to low- and high-intensity thinning measures at deep soil depths, higher fine root biomass and productivity levels were observed in the suitable thinning treatment (Figures 2 and 4). This change could be attributed not only to thinning interventions but also to the regeneration of understory plants [15]. In suitable thinning treatments, the faster regeneration of understory plants excessively consumes resources, which results in greater resource competition pressure in the surface soil and requires trees to adjust their rooting depth and increase their fine root growth at deeper soil depths with less root competition [19]. Thus, we observed the fluctuating phenomena of fine root dynamics in deep soil layers. However, the fine root characteristics at deep soil depths could not recover in a short period of time after thinning (Figures 2 and 4), reflecting their more sensitive response to thinning practices. Moreover, 0.5-1 and 1-2 mm fine roots dominated fine root dynamic characteristics at the deep soil depths and exhibited an increased turnover rate, indicating that thicker fine roots could better mirror potential carbon pools at deeper soil depths in forest ecosystems.

Some studies have reported that fine roots can be categorized according to their functions (e.g., the 1st order of the root system plays a role in absorption) [47,75]. Furthermore, fine root dynamics may vary among different functional plant groups [19]. Although the current study uses a more nuanced classification method that diverges from the traditional definition $(\leq 2 \mathrm{~mm})$ to study stand-level dynamic characteristics of fine roots, future studies could build on root functional approaches and plant functional group distinctions to better understand how root function specificity and species diversity impact belowground processes at the ecosystem level.

\section{Conclusions}


Our study suggests that thinning practices have substantial effects on the dynamic characteristics of multidiameter-class fine roots at different soil depths. The positive effect of thinning on very fine roots and the negative effect on thicker fine roots and all diameter classes of fine roots provide reasonable explanations for the inconsistent effects of thinning practices. Here, 30\% (T2) thinning intensity moderately reduced the aboveground biomass and yielded increased biomass and productivity among very fine roots compared to the other treatments, suggesting that a $30 \%$ approach is a more suitable thinning strategy for promoting productivity and increasing stand heterogeneity in forest ecosystems. Fine root dynamic characteristics at deeper soil depths are more sensitive to thinning measures. The sampled 0.5-1 and 1-2 mm fine roots dominated fine-root dynamic characteristics at deep soil layers and exhibited a higher turnover rate, indicating that thicker fine roots could better mirror potential carbon pools of deeper soils in forest ecosystems. Collectively, our findings provide important insights into the effects of forest management on ecosystem functions and into the climate change mitigation potential of the sequestration of belowground biomass carbon.

\section{Methods}

\section{Study area}

The experiment was implemented at the Qinling National Forest Ecosystem Research Station $\left(33^{\circ} 18^{\prime}-33^{\circ} 28^{\prime} \mathrm{N}, 108^{\circ} 21^{\prime}-108^{\circ} 39^{\prime} \mathrm{E}\right)$ located on the Huoditang Experimental Forest Farm of Northwest A\&F University in Ningshaan County, Shaanxi Province, China. This study area covers an area of 22.25 square kilometers and has a subtropical humid montane climate with altitudes ranging from 1900 to $2200 \mathrm{~m}$ and a mean slope of approximately $35^{\circ}$. Across the site, Cambisols, Umbrisols and Podzols (FAO) are the dominant soil types and reach a mean soil depth of $50 \mathrm{~cm}$ [38]. The annual average temperature and humidity are approximately $10.5^{\circ} \mathrm{C}$ and $77 \%$, respectively. The annual mean precipitation level is $1000 \mathrm{~mm}$ with $50 \%$ occurring from July to September. Local plants have a 177-day growth period, while the average frost-free period of the study area is approximately 199 days [39]. During the 1960s and 1970s, forests around the Qinling National Forest Ecosystem Research Station underwent extensive logging. After decades of regeneration, the forest coverage rate reached $93.8 \%$, and secondary growth dominated the area. The dominant tree species are Quercus aliena var. acutiserrata, Quercus variabilis, Pinus armandii, Betula albosinensis, Picea asperata, and Populus davidiana. Shrubs (i.e., Lonicera tragophylla, Cerasus stipulacea, and Symplocos paniculata) and herbs (i.e., Lysimachia christinae, Rubus parvifolius, Saussurea mutabilis, and Rubia cordifolia) occupy the understory space [40-42].

\section{Experimental design and treatments}

Thinning measures in secondary forest stands (dominated by Pinus armandii, Betula albosinensis, and Picea asperata) were carried out from July to September 2013. All of the selected plots were of the same stand age (35 years), occupied similar topography, and had no history of fertilization. A randomized complete block design was used in the study. Five $20 \times 20 \mathrm{~m}$ plots were randomly installed within each secondary forest block. The whole-tree harvesting method was used, and the following thinning intensities were applied: (1) no thinning (CK), (2) 15\% removal of the stand volume (T1), (3) $30 \%$ removal of the stand volume (T2), (4) $45 \%$ removal of the stand volume (T3), and (5) $60 \%$ removal of the stand volume (T4). To avoid potential edge effects, each plot was surrounded by a 5-m-wide buffer zone. All harvesting materials were removed from the plots. Each of the five thinning treatments was replicated into four blocks, totaling 20 sampling plots (five thinning intensities $\times$ four blocks). The layout of the experimental design is shown in Figure 1 (including blocks and plots).

\section{Soil, litter and vegetation survey}

Soil sampling was conducted at three soil depths $(0-20 \mathrm{~cm}, 20-40 \mathrm{~cm}$ and $40-60 \mathrm{~cm})$ using a soil auger (40 mm diameter) in August 2018. We collected nine replicate soil samples following an "S"-shaped pattern at three depths in each plot (Figure 1). Then, the collected soil samples were fully homogenized from the same depth to form a composite soil sample. In total, 60 composite soil samples ( 5 treatments $\times 4$ blocks $\times 3$ depths) were collected. Plant and fauna residues were manually removed, and the soil was then passed through a $2 \mathrm{~mm}$ screen. The soil samples were then divided into two portions: the first part was air-dried to measure soil organic carbon (SOC), pH, available nitrogen (AN), available phosphorus (AP) and available potassium (AK). The second portion was used to measure the water content after oven-drying at $105^{\circ} \mathrm{C}$ for $48 \mathrm{~h}$. Soil samples of three duplicates were collected at depths of $0-20 \mathrm{~cm}, 20-40 \mathrm{~cm}$ and $40-60 \mathrm{~cm}$ by volumetric rings $\left(100 \mathrm{~cm}^{3}\right)$ after continuously sunny conditions to measure soil bulk density [39, 43]. 
The tree height $(\mathrm{H})$ and diameter at breast height $(\mathrm{DBH} \geq 5 \mathrm{~cm}, 1.3 \mathrm{~m})$ in each plot were measured. Understory species diversity was investigated in five shrub subplots $(2 \times 2 \mathrm{~m})$ and five herb subplots $(1 \times 1 \mathrm{~m})$ established along the diagonals in each plot. Whole plant sampling techniques were used to determine shrub and herb biomass [38]. For litter sampling, all organic material (undecomposed and decomposed parts on the ground) in five $1 \times 1 \mathrm{~m}$ subplots was collected. Herb and litter subplots were located on larger shrub subplots, and all vegetation surveys were carried out in August at peak vegetation coverage as previously described [45].

\section{Fine root sampling}

The sequential soil coring method was used to collect fine root biomass, production, mortality and turnover rate data using a previously described method [46]. Because fine root dynamic processes exhibit strong seasonal variations, fine roots were sampled throughout the year [47]. Furthermore, we expanded the soil depth interval to 0-60 cm based on the average soil layer thickness in the study area.

In each sampling plot, we randomly collected eight soil cores (90 mm inner diameter) over the first three days of September (autumn) and November (winter) 2018 and of April (spring) and June (summer) 2019 (no samples were collected from December to March because low temperatures had caused the soil layer to freeze). We collected samples at depths of 0-20, 20-40 and 40-60 cm using a soil auger, producing 480 ( 5 treatments $\times 4$ blocks $\times 8$ cores $\times 3$ depths) samples seasonally and 1,920 (480 samples $\times 4$ seasons) samples for the four seasons of sampling used for laboratory analysis. The root samples collected at each soil depth were thoroughly mixed to form one fine root sample. In total, 240 root samples ( 5 treatments $\times 4$ blocks $\times 3$ depths $\times 4$ seasons) were collected over the four seasons.

The composite fine root samples were transported to the laboratory in an icebox. To separate the roots from the soil, we first soaked the fine root samples in water. Then, three diameter classes of fine roots $(<0.5,0.5-1$, and $1-2 \mathrm{~mm}$ determined using electronic calipers) were carefully washed and sorted into living and dead groups according to their status using the method described by Brassard et al. (2013) [48]. Live roots were classified as having a pale exterior, as elastic and flexible, and as free of decay with a whitish cortex, while dead roots were brown or black in color and inflexible. Finally, all of the live and dead fine roots of the three diameters were oven-dried at $65^{\circ} \mathrm{C}$ to a constant mass.

\section{Chemical and biochemical analyses}

All soil chemical indicators were determined following a previously described method [43]. The SOC content of soils was measured using the $\mathrm{K}_{2} \mathrm{Cr}_{2} \mathrm{O}_{7}$ oxidation method. Soil available nitrogen (AN) was identified by alkaline hydrolysis diffusion, and available phosphorus (AP) was measured by colorimetry after extraction with $\mathrm{NaHCO}_{3}$. Soil available potassium (AK) was extracted in ammonium acetate $(\mathrm{pH}$ 7.0) and identified on a flame photometer. The soil $\mathrm{pH}$ was determined in a 1:2.5 soil:water suspension. The soil bulk density was obtained by calculating the ratio of soil mass to total volume $\left(\mathrm{g} \mathrm{cm}^{-3}\right)$ after oven drying at $105^{\circ} \mathrm{C}$ to a constant weight [44].

\section{Data calculation and analysis}

Fine root biomass $\left(\mathrm{g} \mathrm{m}^{-2}\right)$ and necromass $\left(\mathrm{g} \mathrm{m}^{-2}\right)$ were calculated for each sampling season in each plot by summing the dry weight of live and dead fine roots in each soil core. Fine root production $\left(\mathrm{g} \mathrm{m}^{-2}\right.$ year $\left.{ }^{-1}\right)$ and mortality $\left(\mathrm{g} \mathrm{m}^{-2}\right.$ year $\left.{ }^{-1}\right)$ were determined using a simplified decision matrix method (Table 2) [19]. The fine root turnover rate (year-1) was defined as the ratio of annual fine root production $\left(\mathrm{g} \mathrm{m}^{-2}\right.$ year $\left.{ }^{-1}\right)$ to the mean biomass $\left(\mathrm{g} \mathrm{m}^{-2}\right)$ of fine roots over a year [49].

In the present study, the biomass characteristics of fine roots were repeatedly measured across sampling seasons by soil depth within each plot. Therefore, we performed a linear mixed model analysis with three fixed effects (thinning intensity $(T)$, sampling season (S), and soil depth (D)) and random effects (plot and block) as described by Feng et al. (2018) and Wang et al. (2019):

$$
Y_{i j k l}=T_{i}+S_{j(l)}+D_{k(l)}+T_{i} \times S_{j(l)}+T_{i} \times D_{k(l)}+S_{j(l)} \times D_{k(l)}+T_{i} \times S_{j(l)} \times D_{k(l)}+\Pi_{l}(1)
$$

where $Y_{i j k l}$ is fine root biomass, necromass, or total mass $\left(\mathrm{g} \mathrm{m}^{-2}\right) ; T_{i}(i=0,15,30,45,60)$ is the thinning intensity; $S_{j(I)}$ is the sample season (i.e., autumn, winter, spring, and summer); $D_{k(l)}$ is the soil depth $(0-20 \mathrm{~cm}, 20-40 \mathrm{~cm}$, and $40-60 \mathrm{~cm})$; and $\pi_{1}$ is a random plot or block effect $(I=1,2, \ldots, 20)$. 
The fine root characteristic percentage change (compared to CK) of the average for all thinning treatments at a certain soil depth could be seen as an indicator for evaluating fine root characteristic responses at different soil depths to thinning intervention. A higher percentage change of one soil depth indicates a more sensitive response to thinning measures, which was calculated as follows:

$$
C_{p}=\frac{\sum_{n=1}^{4}\left(\frac{\left|C_{T_{n}}-C_{C K}\right|}{C_{C K}}\right)}{4} \times 100 \%
$$

2

where $C_{p}$ denotes the fine root biomass, necromass, total mass, production, mortality or turnover rate percentage change value; $T_{n}$ $(n=1,2,3,4)$ is the thinning measure; $C_{T n}$ and $C_{C K}$ are the fine root characteristic mean values for the thinning and control conditions, respectively; and I $\mathrm{C}_{\mathrm{Tn}}-\mathrm{C}_{\mathrm{CK}} \mid$ represents the absolute value of $\mathrm{C}_{\mathrm{Tn}}-\mathrm{C}_{\mathrm{CK}}$.

The effects of thinning intensities on soil properties (water content, bulk density, SOC, AN, AP AK and pH) and stand characteristics (tree density, height, DBH and volume, understory vegetation biomass and species diversity index, and litter biomass) were also tested using a linear mixed-effects model ANOVA. For all models, the significance of fixed effects was assessed using Satterthwaite approximations for degrees of freedom. When fixed effects or interactions were significant, the least square means differences test was performed for multiple comparisons (main effect or simple effect analysis). The statistical value $F$ was used to evaluate the sensitivity differences of three diameter classes of fine roots to thinning measures. The linear mixed-effects model was obtained with the 'ImerTest' and 'Ime4' packages [50, 51]. Multiple comparisons were draw using the 'emmeans' package. Principal component analysis (PCA) was performed to determine the relationships between fine root dynamics and stand characteristics and soil properties, using the 'FactoMineR' package [52]. All analyses were implemented using $\mathrm{R}$ for Windows version 4.1.1 statistical software [53].

\section{Abbreviations}

CK, T1, T2, T3, T4 representing 0\%, 15\%, 30\%, 45\% and 60\% thinning intensity; AN, AP, AK, SOC, WC and BD: available nitrogen, available phosphorus, available potassium, soil organic carbon, water content, soil bulk density; DBH, H, SD, SS, HS, SB, HB, LB: diameter at breast height, tree height, stem density, shrub Shannon-Wiener index, herb Shannon-Wiener index, shrub biomass, herb biomass, litter biomass; $P_{<0.5}, P_{0.5-1}, P_{1-2}:<0.5,0.5-1,1-2 \mathrm{~mm}$ fine root production; $M_{<0.5}, M_{0.5-1}, M_{1-2}:<0.5,0.5-1,1-2$ mm fine root mortality; $\mathrm{T}_{<0.5}, \mathrm{~T}_{0.5-1}, \mathrm{~T}_{1-2}:<0.5,0.5-1,1-2 \mathrm{~mm}$ fine root turnover rate; $\mathrm{B}_{<0.5}, \mathrm{~B}_{0.5-1}, \mathrm{~B}_{1-2}:<0.5,0.5-1,1-2 \mathrm{~mm}$ fine root biomass; $\mathrm{N}_{<0.5}$, $\mathrm{N}_{0.5-1}, \mathrm{~N}_{1-2}:<0.5,0.5-1,1-2 \mathrm{~mm}$ fine root necromass; $\mathrm{L}$ : live fine root mass; $\mathrm{D}$ : dead fine root mass; $\Delta$ represents the changes in living fine root biomass or necromass.

\section{Declarations}

\section{Ethics approval and consent to participate}

Not applicable

\section{Consent for publication}

Not applicable

\section{Availability of data and materials}

The datasets used and/or analysed during the current study are available from the corresponding author on reasonable request.

\section{Competing interests}


The authors have declared that no competing interests exist.

\section{Funding}

This research was supported by the National Natural Science Foundation of China (No.31470644).

\section{Authors' Contributions}

YP designed the experiment; YP, JT carried out the field work and analyzed the data; YP wrote the manuscript; and YP, JT and DW revising the draft manuscript.

\section{Acknowledgments}

We sincerely thank Jiabin Liu, Yang Gao and Xinping Zhang for valuable comments on the manuscript.

\section{References}

1. Fonseca W, Benayas JMR, Alice FE: Carbon accumulation in the biomass and soil of different aged secondary forests in the humid tropics of Costa Rica. Forest Ecology and Management 2011, 262(8):1400-1408.

2. Orihuela-Belmonte D, De Jong B, Mendoza-Vega J, Van der Wal J, Paz-Pellat F, Soto-Pinto L, Flamenco-Sandoval A: Carbon stocks and accumulation rates in tropical secondary forests at the scale of community, landscape and forest type. Agriculture, ecosystems \& environment 2013, 171:72-84.

3. FAO: Global Forest Resources Assessment 2015 In. Rome: The Food and Agricultural Organization of the United Nations (FAO); 2015.

4. Barthlott W, Schmit-Neuerburg V, Nieder J, Engwald S: Diversity and abundance of vascular epiphytes: a comparison of secondary vegetation and primary montane rain forest in the Venezuelan Andes. Plant ecology 2001, 152(2):145-156.

5. Grimwood MJ, Dobbs TJ: The Potential for Species Conservation in Tropical Secondary Forests. Conservation Biology 2010, 23(6):1406-1417.

6. Van Breugel M, Ransijn J, Craven D, Bongers F, Hall JS: Estimating carbon stock in secondary forests: decisions and uncertainties associated with allometric biomass models. Forest ecology and management 2011, 262(8):1648-1657.

7. Emrich A, Pokorny B, Sepp C: The significance of secondary forest management for development policy: GTZ Eschborn, Germany; 2000.

8. Stone R: Nursing China's ailing forests back to health. In.: American Association for the Advancement of Science; 2009.

9. Kammesheidt L: Perspectives on secondary forest management in tropical humid lowland America. AMBIO: A Journal of the Human Environment 2002, 31(3):243-250.

10. Kuehne C, Weiskittel AR, Fraver S, Puettmann KJ: Effects of thinning-induced changes in structural heterogeneity on growth, ingrowth, and mortality in secondary coastal Douglas-fir forests. Canadian Journal of Forest Research 2015, 45(11):14481461.

11. Jörgensen K, Granath G, Lindahl BD, Strengbom J: Forest management to increase carbon sequestration in boreal Pinus sylvestris forests. Plant and Soil 2021:1-14.

12. Tian D-L, Peng Y-Y, Yan W-D, Fang X, Kang W-X, Wang G-J, Chen X-Y: Effects of thinning and litter fall removal on fine root production and soil organic carbon content in Masson pine plantations. Pedosphere 2010, 20(4):486-493.

13. Ding Y, Leppälammi-Kujansuu J, Helmisaari H-S: Fine root longevity and below-and aboveground litter production in a boreal Betula pendula forest. Forest Ecology and Management 2019, 431:17-25.

14. Zhou W, Guan K, Peng B, Tang J, Jin Z, Jiang C, Grant R, Mezbahuddin S: Quantifying carbon budget, crop yields and their responses to environmental variability using the ecosys model for US Midwestern agroecosystems. Agricultural and Forest Meteorology 2021, 307:108521. 
15. Ma Z, Chen HY: Positive species mixture effects on fine root turnover and mortality in natural boreal forests. Soil Biology and Biochemistry 2018, 121:130-137.

16. Yuan Z, Chen HY: Fine root biomass, production, turnover rates, and nutrient contents in boreal forest ecosystems in relation to species, climate, fertility, and stand age: literature review and meta-analyses. Critical Reviews in Plant Sciences 2010, 29(4):204-221.

17. Neumann M, Godbold DL, Hirano Y, Finér L: Improving models of fine root carbon stocks and fluxes in European forests. Journal of Ecology 2020, 108(2):496-514.

18. Aussenac G: Interactions between forest stands and microclimate: ecophysiological aspects and consequences for silviculture. Ann Forest Sci 2000, 57(3):287-301.

19. Wang $\mathrm{D}$, Olatunji $\mathrm{OA}$, Xiao J: Thinning increased fine root production, biomass, turnover rate and understory vegetation yield in a Chinese fir plantation. Forest ecology and management 2019, 440:92-100.

20. Montagnoli A, Terzaghi M, Di lorio A, Scippa GS, Chiatante D: Fine-root morphological and growth traits in a Turkey-oak stand in relation to seasonal changes in soil moisture in the Southern Apennines, Italy. Ecological Research 2012, 27(6):1015-1025.

21. Shen Y, Wang N, Cheng R, Xiao W, Yang S, Guo Y: Short-term effects of low intensity thinning on the fine root dynamics of pinus massoniana plantations in the three gorges reservoir area, China. Forests 2017, 8(11):428.

22. Fukuzawa K, Shibata H, Takagi K, Nomura M, Kurima N, Fukazawa T, Satoh F, Sasa K: Effects of clear-cutting on nitrogen leaching and fine root dynamics in a cool-temperate forested watershed in northern Japan. Forest ecology and management 2006, 225(1-3):257-261.

23. Ma C, Zhang W, Wu M, Xue Y, Ma L, Zhou J: Effect of aboveground intervention on fine root mass, production, and turnover rate in a Chinese cork oak (Quercus variabilis Blume) forest. Plant and soil 2013, 368(1-2):201-214.

24. Liu C, Xiang W, Zou L, Lei P, Zeng Y, Ouyang S, Deng X, Fang X, Liu Z, Peng C: Variation in the functional traits of fine roots is linked to phylogenetics in the common tree species of Chinese subtropical forests. Plant and Soil 2019, 436(1):347-364.

25. Kong D, Ma C, Zhang Q, Li L, Chen X, Zeng H, Guo D: Leading dimensions in absorptive root trait variation across 96 subtropical forest species. New Phytologist 2014, 203(3):863-872.

26. Hertel D, Strecker T, Müller-Haubold H, Leuschner C: Fine root biomass and dynamics in beech forests across a precipitation gradient-is optimal resource partitioning theory applicable to water-limited mature trees? Journal of Ecology 2013, 101(5):1183-1200.

27. McCormack ML, Dickie IA, Eissenstat DM, Fahey TJ, Fernandez CW, Guo D, Helmisaari HS, Hobbie EA, Iversen CM, Jackson RB: Redefining fine roots improves understanding of below-ground contributions to terrestrial biosphere processes. New Phytologist 2015, 207(3):505-518.

28. Shen Y, Wang N, Cheng R, Xiao W, Yang S, Guo Y, Lei L, Zeng L, Wang X: Characteristics of fine roots of Pinus massoniana in the Three Gorges Reservoir Area, China. Forests 2017, 8(6):183.

29. Xiao CW, Sang WG, Wang R-Z: Fine root dynamics and turnover rate in an Asia white birch forest of Donglingshan Mountain, China. Forest Ecology and Management 2008, 255(3-4):765-773.

30. Zobel RW, Kinraide TB, Baligar VC: Fine root diameters can change in response to changes in nutrient concentrations. Plant and Soil 2007, 297(1-2):243-254.

31. Montagnoli A, Di lorio A, Terzaghi M, Trupiano D, Scippa G, Chiatante D: Influence of soil temperature and water content on fineroot seasonal growth of European beech natural forest in Southern Alps, Italy. European Journal of Forest Research 2014, 133(5):957-968.

32. Olesinski J, Lavigne MB, Kershaw Jr JA, Krasowski MJ: Fine-root dynamics change during stand development and in response to thinning in balsam fir (Abies balsamea L. Mill.) forests. Forest Ecology and Management 2012, 286:48-58.

33. Asaye Z, Zewdie S: Fine root dynamics and soil carbon accretion under thinned and un-thinned Cupressus lusitanica stands in, Southern Ethiopia. Plant and soil 2013, 366(1-2):261-271.

34. Peng S, Chen HY: Global responses of fine root biomass and traits to plant species mixtures in terrestrial ecosystems. Global Ecology and Biogeography 2021, 30(1):289-304.

35. Lopez BC, Sabate S, Gracia C: Thinning effects on carbon allocation to fine roots in a Quercus ilex forest. Tree physiology 2003, 23(17):1217-1224.

Page 15/22 
36. Coll L, Balandier P, Picon-Cochard C, Prévosto B, Curt T: Competition for water between beech seedlings and surrounding vegetation in different light and vegetation composition conditions. Ann Forest Sci 2003, 60(7):593-600.

37. Feng C, Wang Z, Zhu Q, Fu S, Chen HY: Rapid increases in fine root biomass and production following cessation of anthropogenic disturbances in degraded forests. Land Degradation \& Development 2018, 29(3):461-470.

38. Pang Y, Tian J, Wang D: Response of multi-ecological component stoichiometry and tree nutrient resorption to medium-term whole-tree harvesting in secondary forests in the Qinling Mountains, China. Forest Ecology and Management 2021, 498:119573.

39. Delian W: Studies on runoff and its water quality in the forestry watershed of Huoditang in Qingling Mountain. Northwest Agriculture and Forestry University of Science and Technology; 2004.

40. Yuan J, Cheng F, Zhu X, Li J, Zhang S: Respiration of downed logs in pine and oak forests in the Qinling Mountains, China. Soil Biology and Biochemistry 2018, 127:1-9.

41. Pang Y, Tian J, Zhao X, Chao Z, Wang Y, Zhang X, Wang D: The linkages of plant, litter and soil C:N:P stoichiometry and nutrient stock in different secondary mixed forest types in the Qinling Mountains, China. PeerJ 2020, 8.

42. Pang Y, Tian J, Liu L, Han L, Wang D: Coupling of different plant functional group, soil, and litter nutrients in a natural secondary mixed forest in the Qinling Mountains, China. Environ Sci Pollut R2021:1-15.

43. Bao S: Soil and agricultural chemistry analysis. In.: China agriculture press, Beijing; 2000.

44. De Vos B, Van Meirvenne M, Quataert P, Deckers J, Muys B: Predictive quality of pedotransfer functions for estimating bulk density of forest soils. Soil Science Society of America Journal 2005, 69(2):500-510.

45. Hart SA, Chen HY: Fire, logging, and overstory affect understory abundance, diversity, and composition in boreal forest. Ecol Monogr 2008, 78(1):123-140.

46. Yuan ZY, Chen HYH: Simplifying the decision matrix for estimating fine root production by the sequential soil coring approach. Acta Oecologica 2013, 48:54-61.

47. Xiong Y, Liu X, Guan W, Liao B, Chen Y, Li M, Zhong C: Fine root functional group based estimates of fine root production and turnover rate in natural mangrove forests. Plant and Soil 2017, 413(1-2):83-95.

48. Brassard BW, Chen HY, Cavard X, Laganière J, Reich PB, Bergeron Y, Pare D, Yuan Z: Tree species diversity increases fine root productivity through increased soil volume filling. Journal of Ecology 2013, 101(1):210-219.

49. Brunner I, Bakker MR, Björk RG, Hirano Y, Lukac M, Aranda X, Børja I, Eldhuset TD, Helmisaari HS, Jourdan C et al: Fine-root turnover rates of European forests revisited: an analysis of data from sequential coring and ingrowth cores. Plant and Soil 2012, 362(1-2):357-372.

50. De Boeck P, Bakker M, Zwitser R, Nivard M, Hofman A, Tuerlinckx F, Partchev I: The estimation of item response models with the Imer function from the Ime4 package in R. Journal of Statistical Software 2011, 39(12):1-28.

51. Kuznetsova A, Brockhoff PB, Christensen RHB: ImerTest package: tests in linear mixed effects models. Journal of Statistical Software 2017, 82(13).

52. Lê S, Josse J, Husson F: FactoMineR: an R package for multivariate analysis. Journal of Statistical Software 2008, 25(1):1-18.

53. R Development Core Team, 2017. R: A Language and Environment for Statstical Computing. Version 3.3.2. R. Foundation for Statistical Computing, http://www.R-project.org/

54. Liao Y, Fan H, Wei X, Wu J, Duan H, Fu X, Liu W, Wang H, Zhan X, Tang P: Competition increased fine root biomass in Chinese fir (Cunninghamia lanceolata) plantations in Subtropical China. Forest Ecology and Management 2019, 435:151-157.

55. Luiro J, Kukkola M, Saarsalmi A, Tamminen P, Helmisaari H-S: Logging residue removal after thinning in boreal forests: longterm impact on the nutrient status of Norway spruce and Scots pine needles. Tree physiology 2010, 30(1):78-88.

56. Lechuga V, Carraro V, Viñegla B, Carreira JA, Linares JC: Managing drought-sensitive forests under global change. Low competition enhances long-term growth and water uptake in Abies pinsapo. Forest Ecology and Management 2017, 406:7282.

57. Noguchi K, Han Q, Araki MG, Kawasaki T, Kaneko S, Takahashi M, Chiba Y: Fine-root dynamics in a young hinoki cypress (Chamaecyparis obtusa) stand for 3 years following thinning. J Forest Res-Jpn 2011, 16(4):284-291. 
58. Eissenstat D, Wells $C$, Yanai R, Whitbeck J: Building roots in a changing environment: implications for root longevity. New Phytologist 2000, 147(1):33-42.

59. Eshel A, Beeckman T: Plant roots: the hidden half: CRC press; 2013.

60. Yin X, Perry JA, Dixon RK: Fine-root dynamics and biomass distribution in a Quercus ecosystem following harvesting. Forest Ecology and Management 1989, 27(3-4):159-177.

61. Metcalfe DB, Meir P, Aragão LEO, da Costa AC, Braga AP, Gonçalves PH, Junior JdAS, de Almeida SS, Dawson LA, Malhi Y: The effects of water availability on root growth and morphology in an Amazon rainforest. Plant and Soil 2008, 311(1-2):189-199.

62. Yuan Z, Chen HY: Fine root dynamics with stand development in the boreal forest. Functional Ecology 2012, 26(4):991-998.

63. Jones RH, Mitchell RJ, Stevens GN, Pecot SD: Controls of fine root dynamics across a gradient of gap sizes in a pine woodland. Oecologia 2003, 134(1):132-143.

64. Schroeer AE, Hendrick RL, Harrington TB: Root, ground cover, and litterfall dynamics within canopy gaps in a slash pine (Pinus elliottii Engelm.) dominated forest. Ecoscience 1999, 6(4):548-555.

65. McGuire JP, Mitchell RJ, Moser EB, Pecot SD, Gjerstad DH, Hedman CW: Gaps in a gappy forest: plant resources, longleaf pine regeneration, and understory response to tree removal in longleaf pine savannas. Canadian Journal of Forest Research 2001, 31(5):765-778.

66. Juodvalkis A, Kairiukstis L, Vasiliauskas R: Effects of thinning on growth of six tree species in north-temperate forests of Lithuania. European Journal of Forest Research 2005, 124(3):187-192.

67. Trentini CP, Campanello PI, Villagra M, Ritter L, Ares A, Goldstein G: Thinning of loblolly pine plantations in subtropical Argentina: Impact on microclimate and understory vegetation. Forest Ecology and Management 2017, 384:236-247.

68. Boot RG: The significance of size and morphology of root systems for nutrient acquisition and competition. SPB Academic Publishing, The Hague: Lambers, H., Cambridge, M.L., Konings, H., Pons, T.L. (Eds.), Causes and Consequences of Variation in Growth Rate and Productivity of Higher Plants; 1989.

69. Joslin J, Gaudinski JB, Torn MS, Riley W, Hanson PJ: Fine-root turnover patterns and their relationship to root diameter and soil depth in a 14C-labeled hardwood forest. New Phytologist 2006, 172(3):523-535.

70. Di lorio A, Montagnoli A, Terzaghi M, Scippa GS, Chiatante D: Effect of tree density on root distribution in Fagus sylvatica stands: a semi-automatic digitising device approach to trench wall method. Trees 2013, 27(6):1503-1513.

71. Sun T, Dong L, Mao Z, Li Y: Fine root dynamics of trees and understorey vegetation in a chronosequence of Betula platyphylla stands. Forest Ecology and Management 2015, 346:1-9.

72. Hertel D, Harteveld MA, Leuschner C: Conversion of a tropical forest into agroforest alters the fine root-related carbon flux to the soil. Soil Biology and Biochemistry 2009, 41(3):481-490.

73. McIntosh AC, Macdonald SE, Quideau SA: Understory plant community composition is associated with fine-scale above-and below-ground resource heterogeneity in mature lodgepole pine (Pinus contorta) forests. PloS one 2016, 11(3):e0151436.

74. Zhang W, Liu W, Xu M, Deng J, Han X, Yang G, Feng Y, Ren G: Response of forest growth to C: N: P stoichiometry in plants and soils during Robinia pseudoacacia afforestation on the Loess Plateau, China. Geoderma 2019, 337:280-289.

75. McKay Fletcher DM, Ruiz S, Dias T, Petroselli C, Roose T: Linking root structure to functionality: the impact of root system architecture on citrate-enhanced phosphate uptake. New Phytologist 2020, 227(2):376-391.

\section{Figures}




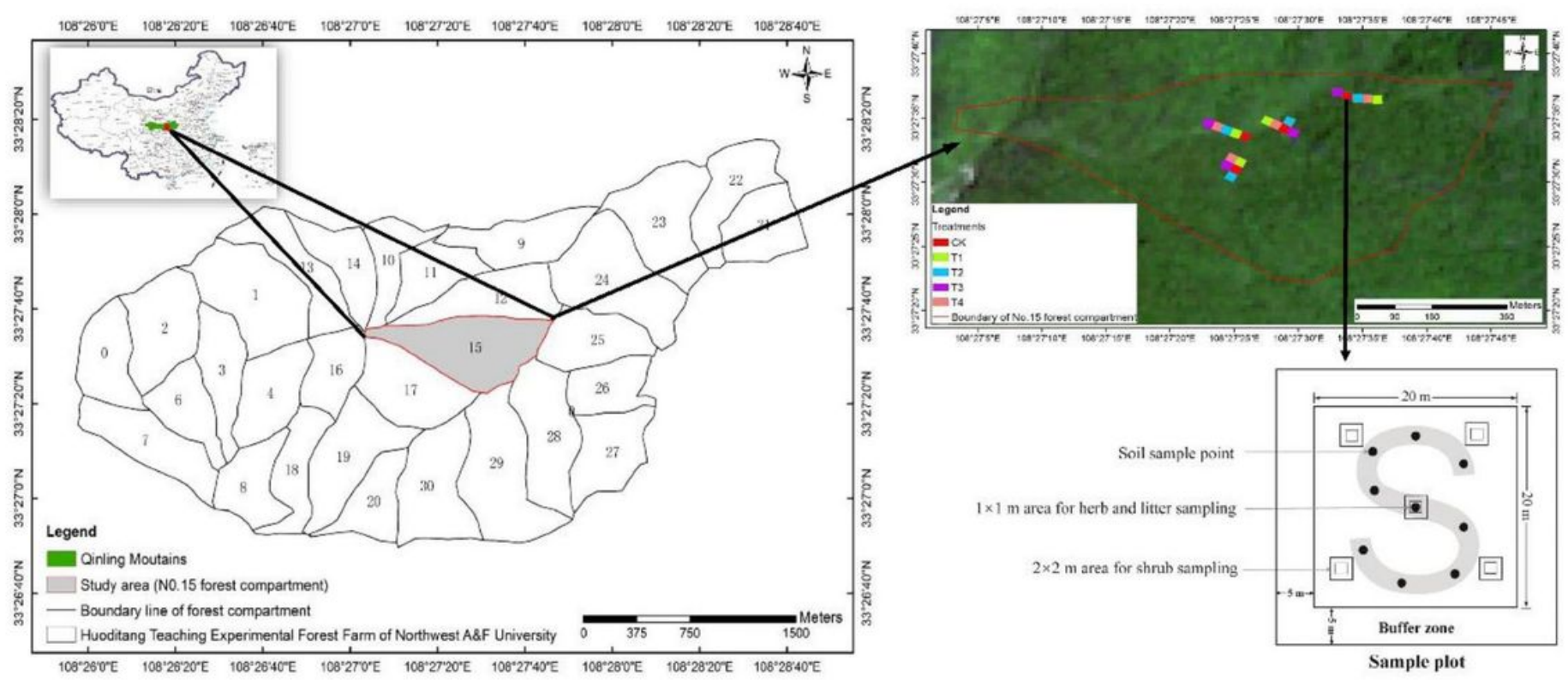

Figure 1

Location of the study area and the layout of experimental plots. CK, T1, T2, T3, T4 representing $0 \%, 15 \%, 30 \%, 45 \%$ and $60 \%$ thinning intensity, respectively. 
Biomass
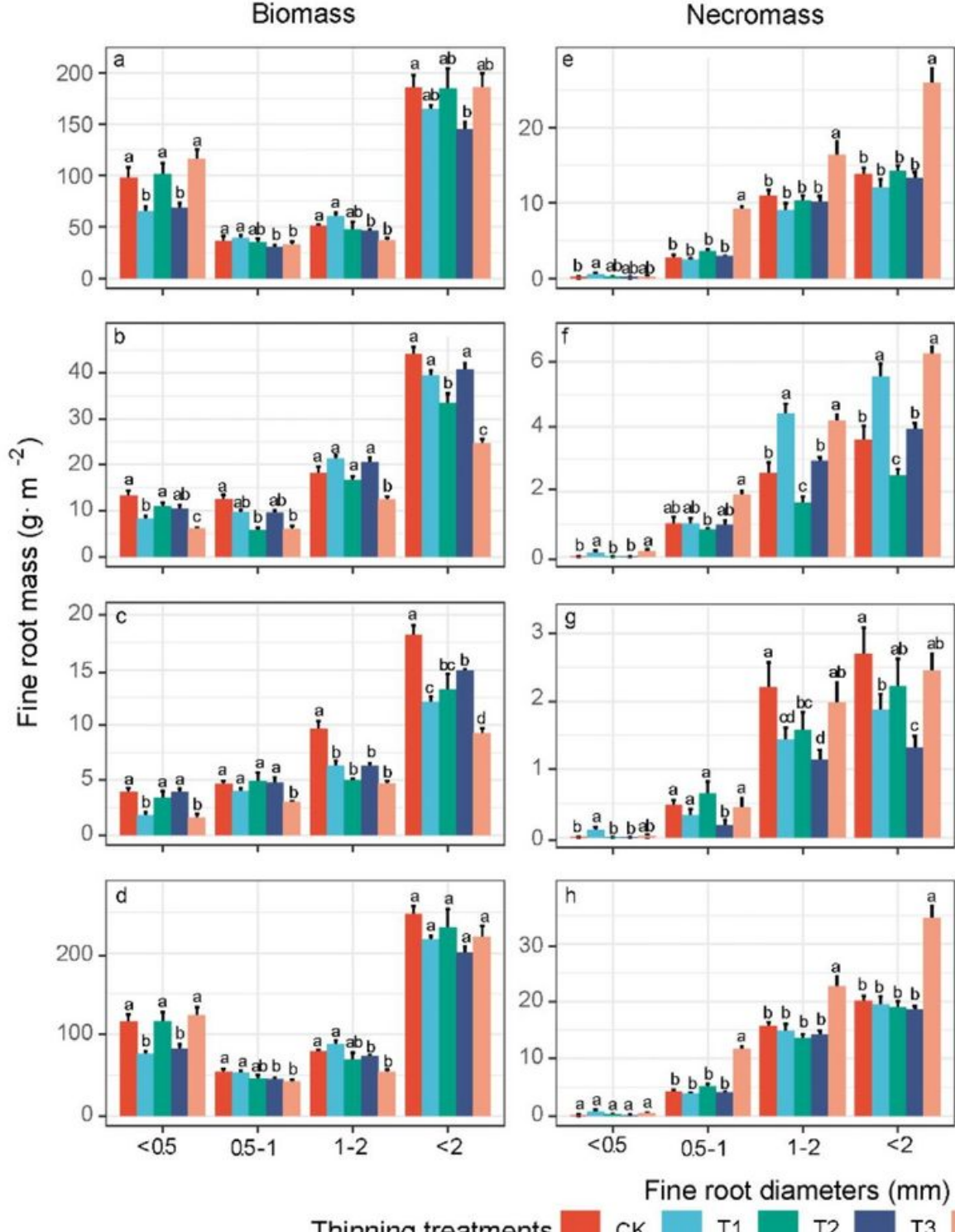

Totall mass
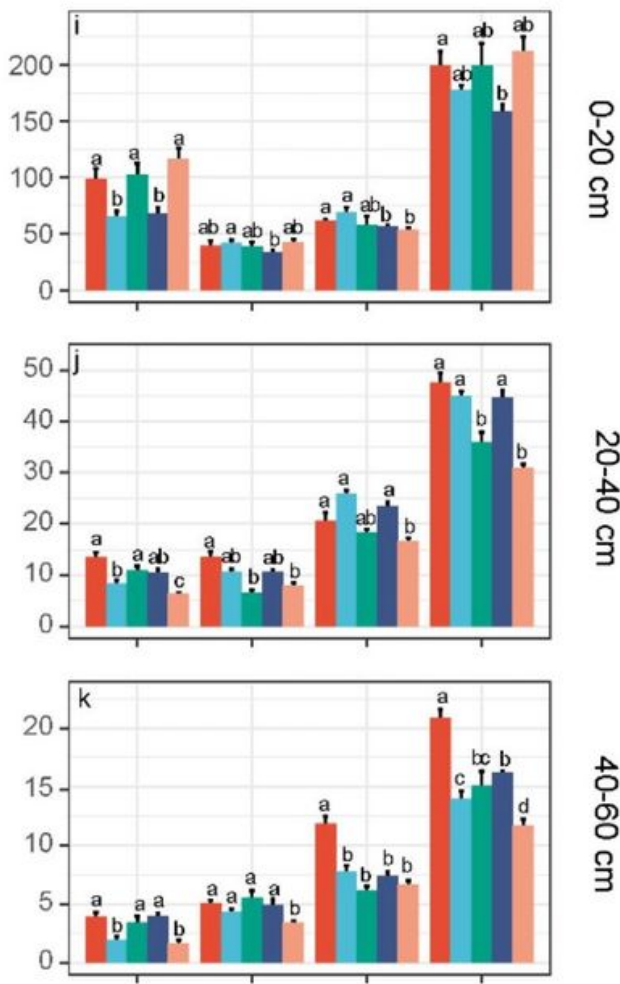

to
Oे
0
3

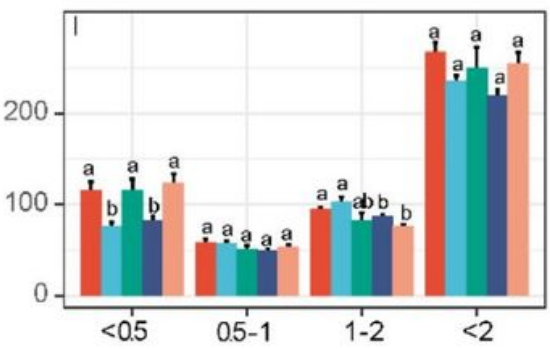

옹
잉

\section{Figure 2}

The effects of thinning intensities on the fine root biomass, necromass, and total mass (average over 4 seasons) among different diameter classes in different soil depths (a-c, e- $\mathrm{g}$ and $\mathrm{i}-\mathrm{k}$ ) and entire soil profile ( $\mathrm{d}, \mathrm{h}$ and $\mathrm{I})$. Values are the mean of 4 replicates $\pm \mathrm{SE}$. CK, T1, T2, T3, T4 representing $0 \%, 15 \%, 30 \%, 45 \%$ and $60 \%$ thinning intensity, respectively. Different lowercase letters (a, b, c, d) indicate significant differences for same diameter class fine roots among thinning intensities $(p<0.05)$. 


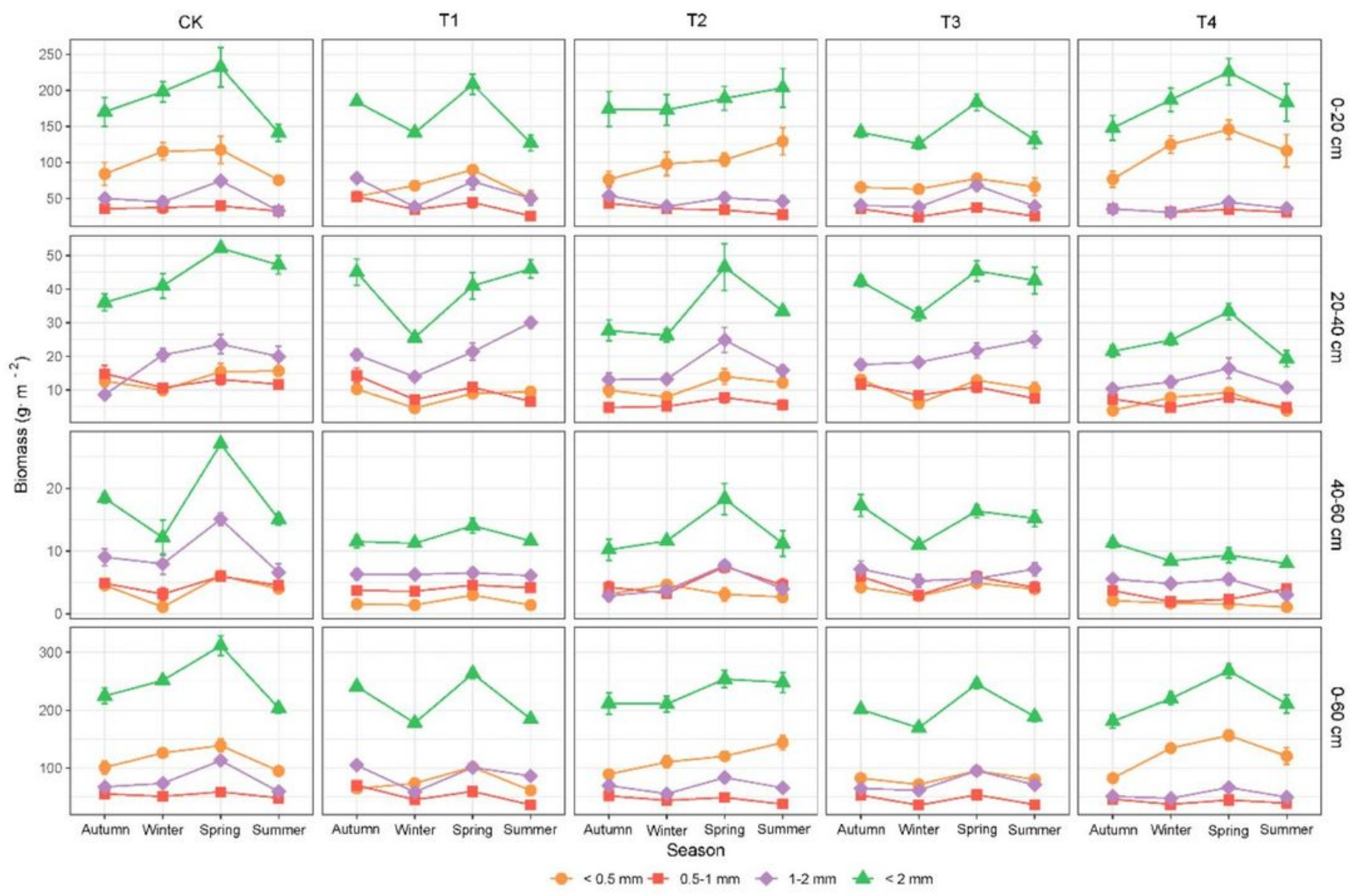

Figure 3

The effects of season on the fine root biomass (live) among different diameter classes in different soil depths and entire soil profile. Values are the mean of 4 replicates \pm SE. CK, T1, T2, T3, T4 representing $0 \%, 15 \%, 30 \%, 45 \%$ and $60 \%$ thinning intensity, respectively. 


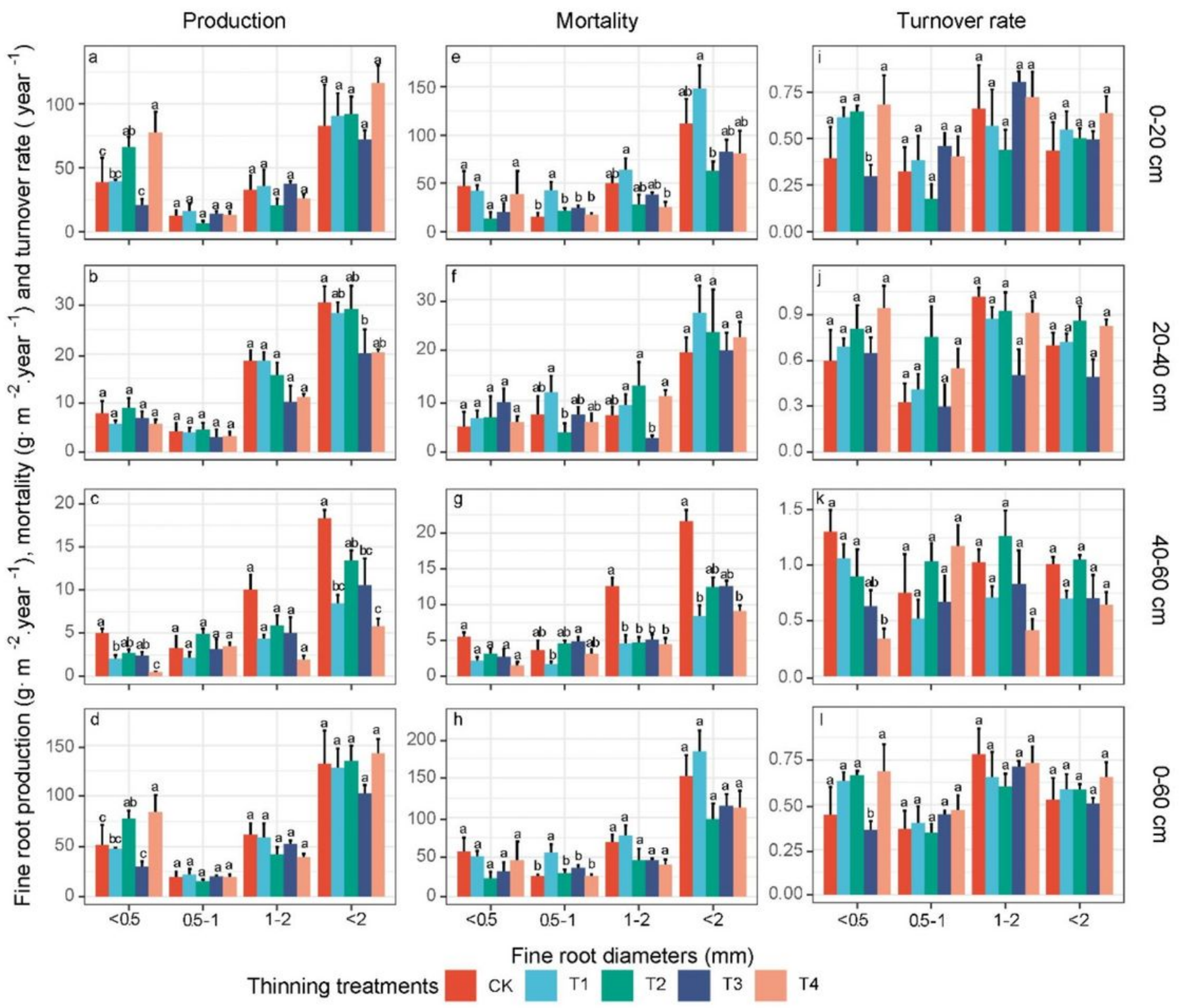

Figure 4

The effects of thinning intensities on fine root production, mortality and turnover rate among different diameter classes in different soil depths (a-c, e-g and $i-k)$ and entire soil profile ( $d, h$ and I). Values are the mean of 4 replicates $\pm S E$. CK, T1, T2, T3, T4 representing $0 \%, 15 \%, 30 \%, 45 \%$ and $60 \%$ thinning intensity, respectively. Different lowercase letters (a, b, c, d) indicate significant differences for same diameter class fine roots among thinning intensities $(p<0.05)$. 


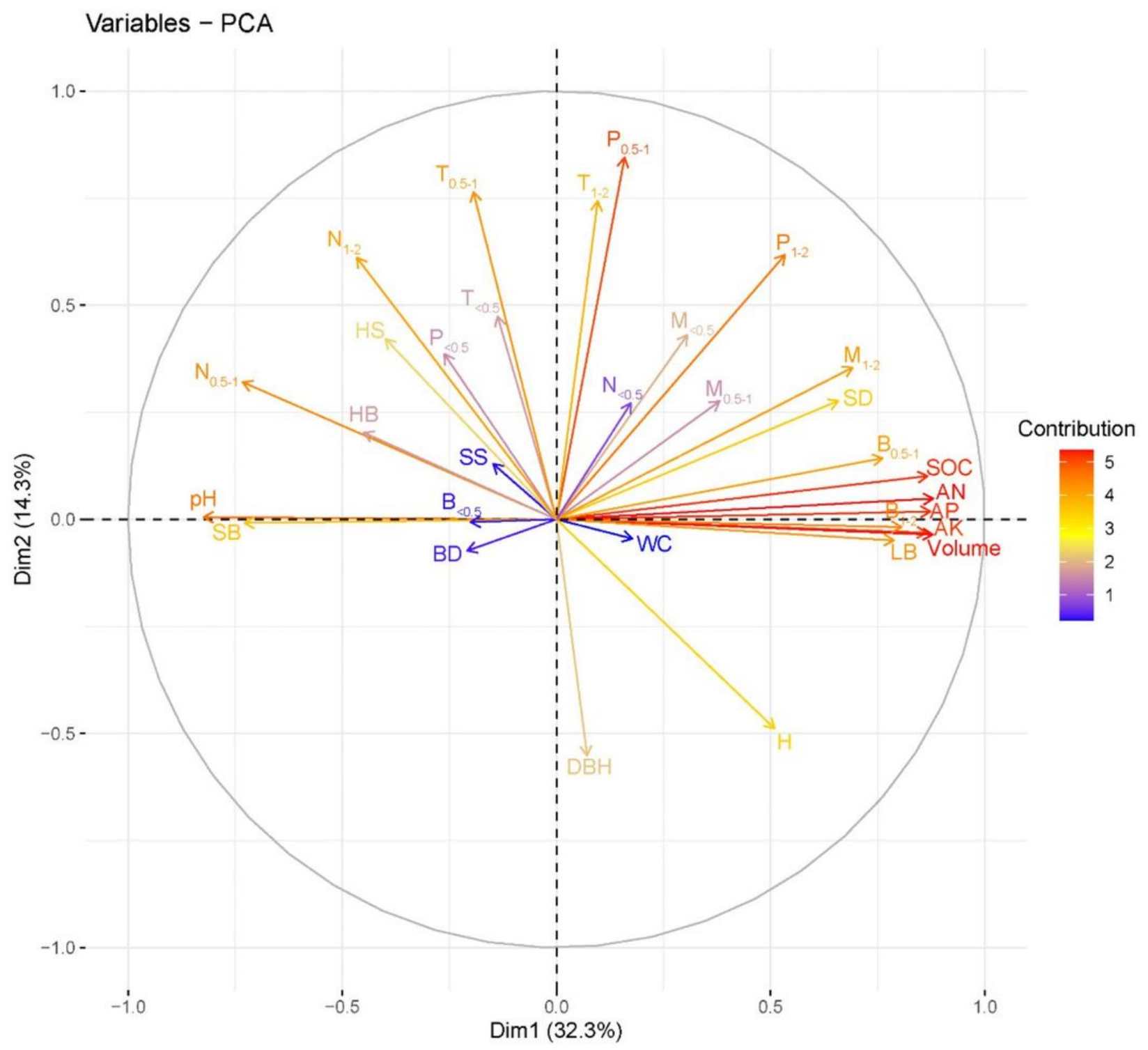

\section{Figure 5}

Principal component analysis over entire soil profile among fine root dynamics and stand attributes and soil properties. The arrow of each variable represents the correlation coefficient between the variable and the first two principal components in the unit circle; variables are colored by their contributions (\%) to the variance in the principal component (see corresponding eigenvalues and eigenvectors in Tables S2 and S3). AN, AP, AK, SOC, WC and BD: available nitrogen, available phosphorus, available potassium, soil organic carbon, water content, soil bulk density; DBH, H, SD, SS, HS, SB, HB, LB: diameter at breast height, tree height, stem density, shrub Shannon-Wiener index, herb Shannon-Wiener index, shrub biomass, herb biomass, litter biomass; $\mathrm{P}<0.5, \mathrm{P} 0.5-1, \mathrm{P} 1-2:<0.5$, 0.5-1, 1-2 mm fine root production; M<0.5, M0.5-1, M1-2: < 0.5, 0.5-1, 1-2 mm fine root mortality; T<0.5, T0.5-1, T1-2: $<0.5,0.5-1,1-2$ $\mathrm{mm}$ fine root turnover rate; $\mathrm{B}<0.5, \mathrm{~B} 0.5-1, \mathrm{~B} 1-2:<0.5,0.5-1,1-2 \mathrm{~mm}$ fine root biomass; $\mathrm{N}<0.5, \mathrm{~N} 0.5-1, \mathrm{~N} 1-2:<0.5,0.5-1,1-2 \mathrm{~mm}$ fine root necromass.

\section{Supplementary Files}

This is a list of supplementary files associated with this preprint. Click to download.

- Supplementarymaterials.docx

Page 22/22 